\title{
PERANCANGAN MULTIMEDIA INTERAKTIF UNTUK PENTAS WAYANG ORANG RAMAYANA SEBAGAI UPAYA MENINGKATKAN MINAT GENERASI MUDA DALAM PELESTARIAN BUDAYA DI KOTA SURAKARTA
}

\author{
Sugiyanto ${ }^{1}$, Godham Eko Saputro ${ }^{2}$, Nur Rohman ${ }^{3}$ \\ ${ }^{1,3}$ Program Studi Animasi, Fakultas IImu Komputer, Universitas Dian Nuswantoro \\ ${ }^{2}$ Program Studi Desain Komunikasi Visual, Fakultas IImu Komputer, Universitas \\ Dian Nuswantoro
}

\begin{abstract}
Abstrak: Wayang orang sebagai drama tari tradisional saat ini sudah tidak menarik lagi bagi generasi muda karena hadirnya hiburan modern yang lebih canggih seperti yang berbasiskan multimedia. Keunggulan multimedia adalah dapat menciptakan presentasi dinamis menggunakan teks, grafik, animasi, audio, dan video. Setiap elemen dalam multimedia dapat diadaptasi untuk pertunjukan, salah satunya adalah kesenian tradisional wayang orang. Gebrakan baru yang dilakukan adalah pengaplikasian multimedia interaktif menggunakan visualisasi 3 dimensi beserta sound effect-nya sebagai background pentas, karena usaha meningkatkan minat generasi muda akan lebih efektif dan efisien apabila media yang digunakan adalah media yang memang familiar dengan mereka. Ada 2 metode dengan tujuan berbeda disini; metode pengumpulan data lebih dulu disusul metode perancangan atau pengembangan. Dari hal tersebut maka penetrasi melalui multimedia interaktif adalah salah satu usaha dalam pelestarian pentas wayang orang Ramayana.
\end{abstract}

Kata kunci: wayang orang, ramayana, tradisional, multimedia, animasi

\begin{abstract}
Wayang Orang as a traditional dance drama is now no longer of interest to the younger generation because of the presence of modern entertainment more sophisticated as it is based on multimedia. Multimedia excellence is able to create dynamic presentations using text, graphics, animation, audio, and video. Each element in a multimedia can be adapted for the show, one of which is a traditional art wayang orang. Made new breakthrough is an interactive multimedia application using a $3 d$ visualization along with its sound effects as background scene, as an effort to increase interest in the younger generation will be more effective and efficient when used media is that familiar to them. There are two methods with different purposes here; first data collection methods followed by method of designing or development. From these two penetrating through interactive multimedia is one of the efforts in the preservation of the Ramayana wayang orang stage.
\end{abstract}

Keywords: wayang orang, Ramayana, traditional, multimedia, animation

Penulis adalah para staf pengajar di Universitas Dian Nuswantoro Semarang, email: sugiyanto@dsn.dinus.ac.id ${ }^{1}$,godham.eko@gmail.com ${ }^{2}$, nurrokhman2012@gmail.com ${ }^{3}$ 


\section{PENDAHULUAN}

Wayang orang atau popular disebut wayang wongialah sebuah jenis yang digolongkan ke dalam bentuk drama tari tradisional. Negerikuindonesia.com mendefinisikan wayang wong merupakan suatu perpaduan seni drama, tari dan cerita pewayangan yang di kemas menjadi satu dalam suatu pertunjukan. Seni pertunjukan merupakan sebuah seni kolektif yang dalam menampilkannya di atas panggung dibutuhkan biaya yang dapat dibilang cukup mahal, mulai dari penataan panggung, penataan musik, busana, tata rias hingga penari membutuhkan estimasi dana yang tidak sedikit (Soedarsono, 2002).

Pentas luar ruang Taman Balekambang merupakan bagian komplek Taman Balekambang Surakarta yangsering dimanfaatkan untuk mementaskan pertunjukan wayang orang (sendratari) Ramayana dimanadapat menampung sekitar 500 penonton. Namun sangat disayangkan, pertunjukan wayang orang kian terpinggirkan karena kurang dapat menarik minat masyarakat. perkembangan jumlah penonton pertunjukan wayang orang mengalami penurunan dari tahun ke tahun. Tabel dibawah menunjukkan bahwa usia di bawah 40 tahun mengalami tingkat penurunan yang signifikan.

\begin{tabular}{|c|c|c|c|c|c|c|}
\multirow{2}{*}{ No. } & \multicolumn{2}{|c|}{ Periode } & \multicolumn{5}{|c|}{ Kategori Usia (Tahun) } \\
\cline { 3 - 7 } & & $<15$ & $16-20$ & $21-30$ & $31-40$ & $>41$ \\
\hline 1. & Tahun 2005 & - & $5 \%$ & $15 \%$ & $35 \%$ & $45 \%$ \\
\hline 2. & Tahun 2006 & - & $1 \%$ & $10 \%$ & $36 \%$ & $53 \%$ \\
\hline 3. & Tahun 2007 & - & - & $12 \%$ & $30 \%$ & $58 \%$ \\
\hline 4. & Tahun 2008 & - & - & $10 \%$ & $25 \%$ & $65 \%$ \\
\hline
\end{tabular}

Gambar 1. Data penurunan penonton wayang orang Sumber: http://www.stpsahidsolo.ac.id/index.php?id=artikel\&kode=

Hersapandi (1999) penulis buku Wayang Wong Sriwedari Dari Istana Menjadi Seni Komersial menyebutkan bahwa beberapa faktor penyebab 
kemunduran seni pertunjukan wayang orang adalah: Keterlambatan alih generasi dimana masih banyak bertahan pemain senior, pertunjukan yang terkesan monoton dan statis dikarenakan kondisi gedung pertunjukan yang terbatas, manajemen yang kurang profesional, kurangnya sarana pendukung terutama gedung yang representatif, kurangnya kenyamanan penonton dalam menyaksikan wayang orang, dan tingkat pendidikan para pemain yang rendah.

Bila ditilik memang perkembangan teknologi informasi dan komunikasi saat ini memberikan banyak pilihan hiburan yang lebih menarik (internet, game, dan media sosial). Tidak dapat dipungkiri hal-hal yang berbau tradisional sudah tidak menarik lagi seiring dengan perkembangan zaman. Hal ini membawa dampak terhadap pandangan penonton yang tadinya menganggap wayang orang adalah pertunjukan yang menarik menjadi sebuah pandangan bahwa wayang orang hanya kesenian tradisional yang sudah lapuk termakan zaman. Para generasi muda tidak memiliki peminatan yang besar karena hadirnya hiburan yang lebih canggih.

Turban dkk (2002) menyebutkan bahwa multimedia adalah kombinasi dari paling sedikit dua media masukan atau keluaran dari data, media ini dapat audio (suara, musik), animasi, video, teks, grafik dan gambar sedangkan Robin \&Linda, 2001 dalam digitalview.weebly.com menyebutkan bahwa multimedia merupakan alat yang dapat menciptakan presentasi yang dinamis atau interaktif yang mengkombinasikan teks, grafik, animasi, audio, dan gambar video. Dengan akan dimanfaatkannya perkembangan perangkat yang mendukung multimedia dalam pertunjukan wayang orang, elemen-elemen multimedia telah memberikan dukungan penyampaian informasi dari setiap adegan kepada penonton. Selain itu, penggabungan elemen-elemen multimedia (animasi dan audio effect) dengan sendratari memberikan pengalaman baru yang dapat menarik minat penonton untuk hadir dalam pertunjukan wayang orang. Sehingga penulis berkesimpulan bahwa perancangan multimedia interaktif untuk pentas wayang 
orang ramayana sebagai upaya meningkatkan minat generasi muda dalam pelestarian budaya di kota Surakarta, diharapkan dapat menciptakan pengalaman baru, interaksi yang lebih intens, serta dapat menarik banyak pengunjung dari kalangan kawula muda.

\section{KAJIAN TEORI}

Wayang Orang

Wayang menurut KBBI Edisi III adalah (1) boneka tiruan orang yang terbuat dari pahatan kulit atau kayu dan sebagainya yang dapat dimanfaatkan untuk memerankan tokoh dalam pertunjukan drama tradisional (Bali, Jawa, Sunda, dan sebagainya), biasanya dimainkan oleh seseorang yang disebut dalang; (2) pertunjukan wayang (selengkapnya); (3) ki pelaku (yang hanya sebagai pelaku, bukan sebagai perencana); orang suruhan yang harus bertindak sesuai dengan perintah orang lain: penembak calon presiden itu hanya - bukan dalangnya; (4) bayang-bayang, sedangkan wong (jawa) berarti orang. Wayang dapat diidentifikasi jenisnya, seperti; wayang golek, wayang kulit, serta wayang orang.

Dalam sejarahnya, wayang orang adalah hasil kreasi Kanjeng Pangeran Adipati Arya Mangkunegara I (1757 - 1795), tergolong seni pertunjukan yang menampilkan cerita Ramayana dan Mahabharata. Menyandang nama wayang orang, wayang jenis ini menampilkan pemain asli dari manusia, tidak menggunakan boneka dari kulit kerbau. Para pemain ini memakai riasan wajah/ make up berupa gambar atau lukisan beserta kostum dan hiasan persis yang dipakai wayang kulit. Kostum yang dipakai adalah pakaian adat keraton sehari-hari yang dipadu dengan selendang tari sehingga terkesan gemerlap. Pertunjukan yang ditampilkan berupa tarian ketika masuk dan keluar panggung, perang, dan diselingi dengan berbagai lagu Jawa yang diiringi dengan alat musik tradisional gamelan berjenis pelog dan slendro. Lama pementasan bekisar 7 atau 8 jam pada malam hari untuk lakon utama. Dalam pementasannya, wayang orang juga 
memerlukan dalang layaknya seorang sutradara, yang bertugas sebagai pengatur perpindahan antar adegan menggunakan suara monolog/ suluk.

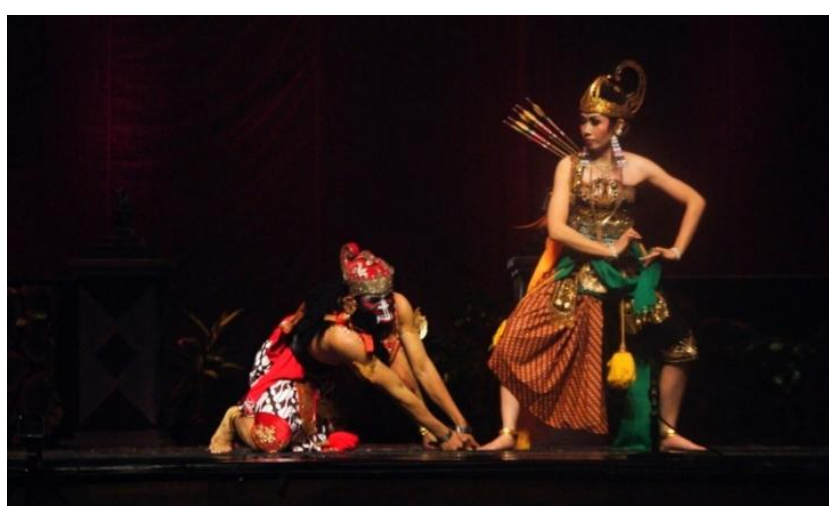

Gambar 2. Wayang orang ramayana [Sumber: jogjanews.com]

\section{A. Multimedia}

Multimedia berasal dari kata multi yang berarti banyak dan media yang berarti perantara. Multimedia dapat menyajikan dan menggabungkan teks, suara, gambar, animasi, dan video dengan alat bantu (tool) dan koneksi (link) sehingga pengguna dapat melakukan navigasi, berinteraksi, berkarya dan berkomunikasi.Menurut Green \& Brown(2002: 2-6) Multimedia interaktif menggabungkan dan mensinergikan semua media yang terdiri dari:teks, grafik, audio, video, animasi dan interaktivitas.

\section{METODE PENELITIAN}

Terdapat metode pengumpulan data dan metode perancangan/ pengembangan. Untuk memperoleh informasi yang dibutuhkan, berikut adalah metode pengumpulan data :

\section{a. Observasi (pengamatan)}

Observasi dilakukan dengan beberapa kali menonton pentas wayang orang (sendra tari) Ramayana yang diselenggarakan di Taman Balekambang. Disini peneliti akan mengamati secara langsung bagaimana pentas diluar ruang 
dilaksanakan dan mengidentifikasi hal-hal yang terkait dengan perancangan. Pada proses ini akan menghasilkan data aktual dan faktual, karena data didapatkan saat dilangsungkannya pentas diluar ruang. Adapun data-data yang didapatkan saat dilakukannya observasi antara lain: situasi dan kondisi pentas luar ruang di Taman Balekambang, jadwal wayang orang yang menggunakan pentas luar ruang, dan situasi saat pentas luar ruang digunakan.

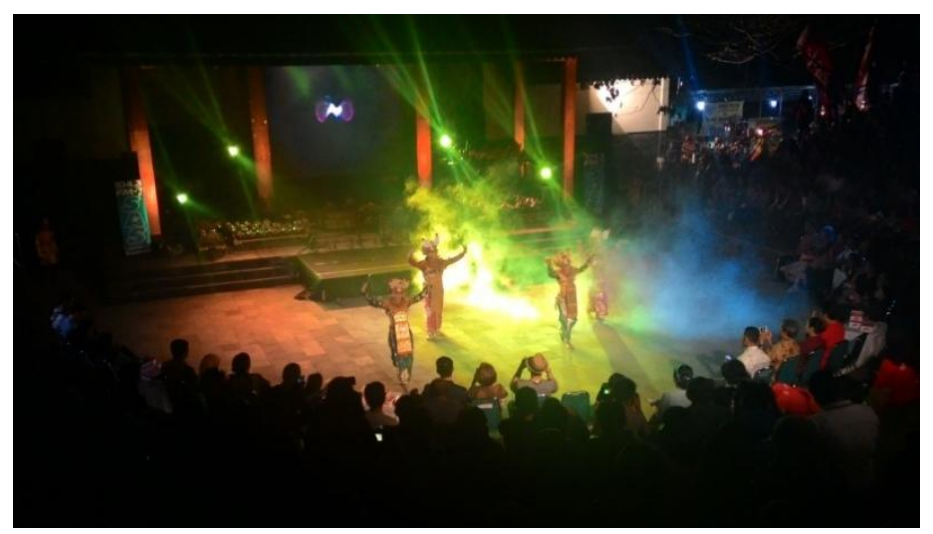

Gambar 3.Observasi pentas luar ruang taman balekambang Sumber: dokumentasi penulis

\section{b. Wawancara}

Adapun wawancara dilakukan dengan Dra. Endang Sri Murniyati, selaku Kepala UPTD/ Pengelola Taman Balekambang, Drs. Sidik Suradi, selaku Seniman/pimpinan sanggar Sang Rama Budaya, dalang pentas Ramayana, serta masyarakat pengunjung Taman Balekambang Surakarta.

\section{c. Studi pustaka}

Studi pustaka merujuk pada buku, jurnal penelitian, dan artikel (online maupun offline).

\section{METODE PERANCANGAN}

Dalam penelitian ini menggunakan metode perancangan berupa metode pengembangan multimedia Arch C. Luther, dimana dilakukan dengan enam 
tahap, antara lain; konsep (concept), desain (design), pengumpulan materi (material collecting), pembuatan (assembly), pengujian (testing), dan pendistribusian (distribution). Luther menjelaskan bahwa enam tahap ini tidak harus berurutan tetapi dapat saling bertukar posisi kecuali tahap konsep.

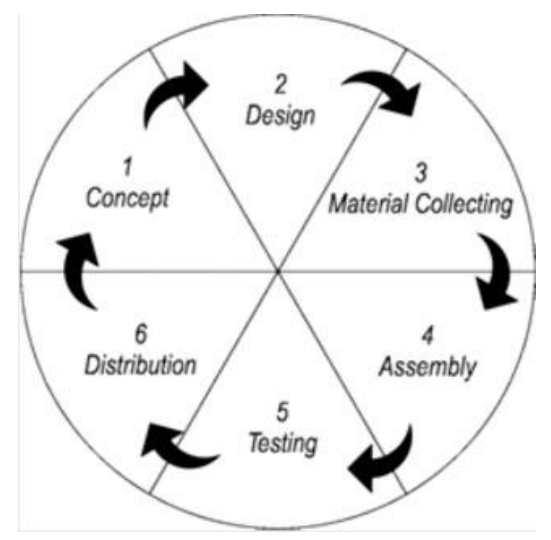

Gambar 4. Tahap pengembangan multimedia sumber :Authoring Interactive Multimedia

\section{Konsep(Concept)}

Tahap awal adalah konsep dimanaide atau gagasan yang menentukan tujuan dan target audiens-nya, konsep biasanya melalui proses yang panjang sehingga menghasilkan model interaktif yang kreatif dan inovatif.

\section{Desain(Design)}

Desain adalah merancang sebuah spesifikasi secara rinci terkait arsitektur program, tampilan, gaya, dan material/ bahan untuk sebuah program. Tahap desain lazimnya menggunakan storyboard, dengan mencantumkan semua objek multimedia dan tautan ke scene lain dan bagan alir (flowchart) untuk menggambarkan aliran dari satu scene ke scene lain.

\section{Pengumpulan bahan(Material Collecting)}

Pengumpulan bahanmerupakan tahap pengumpulan kebutuhan yang dikerjakanseperti gambar, foto, animasi, video, audio, dan lain-lain yang dapat menggunakan jasa desainer atau mengunduh gratis sesuai kebutuhan. 


\section{Pembuatan(Assembly)}

Tahap pembuatan mencakup pembuatan semua bahan multimedia berdasarkanstoryboard, bagan alir (flowchart), dan struktur navigasi.

\section{Pengujian(Testing)}

Tahap ini adalah menguji aplikasi tersebut dan dilihat apakah masih terdapat kesalahan. Pengujian alpha (tahap pertama) dilakukan oleh si pembuat. ketika lolos pengujian alpha, dilanjutkan dengan pengujian beta oleh pengguna akhir.

\section{Distribusi(Distribution)}

Pada tahap akhir ini aplikasi didistribusikan ke target audiens. Selain itu pembuat dapat melakukan evaluasi untuk pengembangan produk yang lebih baik.

HASIL DAN DISKUSI

Konsep perancangan multimedia interaktif untuk pentas wayang orang ramayana

Dari hasil pengamatan, wawancara, dan studi pustaka, konsep multimedia interaktif yang akan dibuat adalah Video Animasi3D sebagai background pentas wayang orang Ramayana yang berubah sesuai tema setiap adegan, menggunakan LED display/ LCD Proyektor sebagai media display dipadu dengan lighting sebagai unsur artisitik pementasan dan sound effect yang ikut membangun suasana sesuai adegan.

Desain perancangan multimedia interaktif untuk pentas wayang orang ramayana

Pada tahapan desain ini, dibuat rundown Adegan Cerita Ramayana Full Story "Baratayuda Kudup Sari Pawaga" beserta sket gambar background yang telah disepakati dengan dalang. 
RundownAdegan Cerita Ramayana Full Story “Baratayuda Kudup Sari Pawaga”

\begin{tabular}{|c|c|c|c|c|}
\hline NO & ADEGAN & RINCIAN ADEGAN & SETING & DURASI \\
\hline \multirow[t]{8}{*}{1} & \multirow[t]{8}{*}{$\begin{array}{l}\text { SINTA } \\
\text { DICULIK }\end{array}$} & $\begin{array}{l}\text { Pengembaraan Rama, Sinta dan } \\
\text { Laksmana: }\end{array}$ & Hutan & $\begin{array}{l}10 \\
\text { Menit }\end{array}$ \\
\hline & & - Kijang emas menggoda Sinta & & \\
\hline & & - Pengejaran Kijang oleh Rama & & \\
\hline & & $\begin{array}{l}\text { - Rahwana berubah menjadi orang } \\
\text { tua. }\end{array}$ & - Hutan & 5 Menit \\
\hline & & - Sinta diculik & & \\
\hline & & - Garuda Jatayu Kiprah & - Mega/ awan & 8 Menit \\
\hline & & $\begin{array}{l}\text { - Perang dengan Rahwana, Jatayu } \\
\text { kalah }\end{array}$ & & \\
\hline & & - Rama, Laksmana bertemu Jatayu & - Daratan & 5 Menit \\
\hline \multirow[t]{3}{*}{2} & \multirow{3}{*}{$\begin{array}{l}\text { PERANG } \\
\text { SAUDARA } \\
\text { SUGRIWA } \\
\text { SUBALI }\end{array}$} & - Peperangan Sugriwa Subali & - Medan perang & \multirow[t]{2}{*}{7 Menit } \\
\hline & & - Sugriwa bertemu Rama & - background pepohonan & \\
\hline & & $\begin{array}{l}\text { - Subali gugur, Sugriwa dan bala } \\
\text { tentara kera bergabung dengan } \\
\text { Rama }\end{array}$ & - background pepohonan & 8 Menit \\
\hline \multirow[t]{2}{*}{3} & \multirow[t]{2}{*}{$\begin{array}{l}\text { ANOMAN } \\
\text { DUTA }\end{array}$} & $\begin{array}{l}\text { - Rama Sugriwa berembuk untuk } \\
\text { memilih duta ke Alengka }\end{array}$ & $\begin{array}{l}\text { - Kerajaan di Hutan, } \\
\text { bebatuan } \begin{array}{l}\text { tertata } \\
\text { sebagai singgasana }\end{array}\end{array}$ & 5 Menit \\
\hline & & - Anoman berangkat & - Daratan, awan & 5 Menit \\
\hline \multirow[t]{3}{*}{4} & \multirow{3}{*}{$\begin{array}{l}\text { TAMAN } \\
\text { ALENGKA }\end{array}$} & - Sinta, Trijatha, Rahwana & - Taman & \multirow{3}{*}{$\begin{array}{l}15 \\
\text { Menit }\end{array}$} \\
\hline & & - Datang Anoman & - Alun-alun & \\
\hline & & - Anoman Obong & - Bara api & \\
\hline \multirow[t]{2}{*}{5} & \multirow{2}{*}{$\begin{array}{l}\text { RAMA } \\
\text { TAMBAK }\end{array}$} & \multirow[t]{2}{*}{ - Bala tentara kera menuju Alengka } & - Daratan & \multirow{2}{*}{$\begin{array}{l}10 \\
\text { Menit }\end{array}$} \\
\hline & & & - Lautan & \\
\hline \multirow[t]{2}{*}{6} & \multirow{2}{*}{$\begin{array}{l}\text { BARATA } \\
\text { YUDA } \\
\text { KUDUP } \\
\text { SARI } \\
\text { PAWAGA }\end{array}$} & \multirow{2}{*}{$\begin{array}{l}\text { - Perang besar kubu Rama dengan } \\
\text { Alengka sampai Rahwana Gugur }\end{array}$} & - Medan laga & \multirow{2}{*}{$\begin{array}{l}15 \\
\text { Menit }\end{array}$} \\
\hline & & & $\begin{array}{l}\text { - Berserakan puing-puing } \\
\text { kereta, Gajah, dan } \\
\text { properti tameng, gada, } \\
\text { tombak, dsb. }\end{array}$ & \\
\hline \multirow[t]{2}{*}{7} & \multirow{2}{*}{$\begin{array}{l}\text { SINTA } \\
\text { OBONG }\end{array}$} & \multirow[t]{2}{*}{ - Pembuktian kesucian Sinta } & - Alun alun & \multirow{2}{*}{$\begin{array}{l}10 \\
\text { Menit }\end{array}$} \\
\hline & & & - Bara api & \\
\hline
\end{tabular}

\section{Sketsa background}

Sketsa background digunakan sebagai acuan dalam produksi desain background. Berikut ini beberapa sketsabackground yang telah dibuat : 

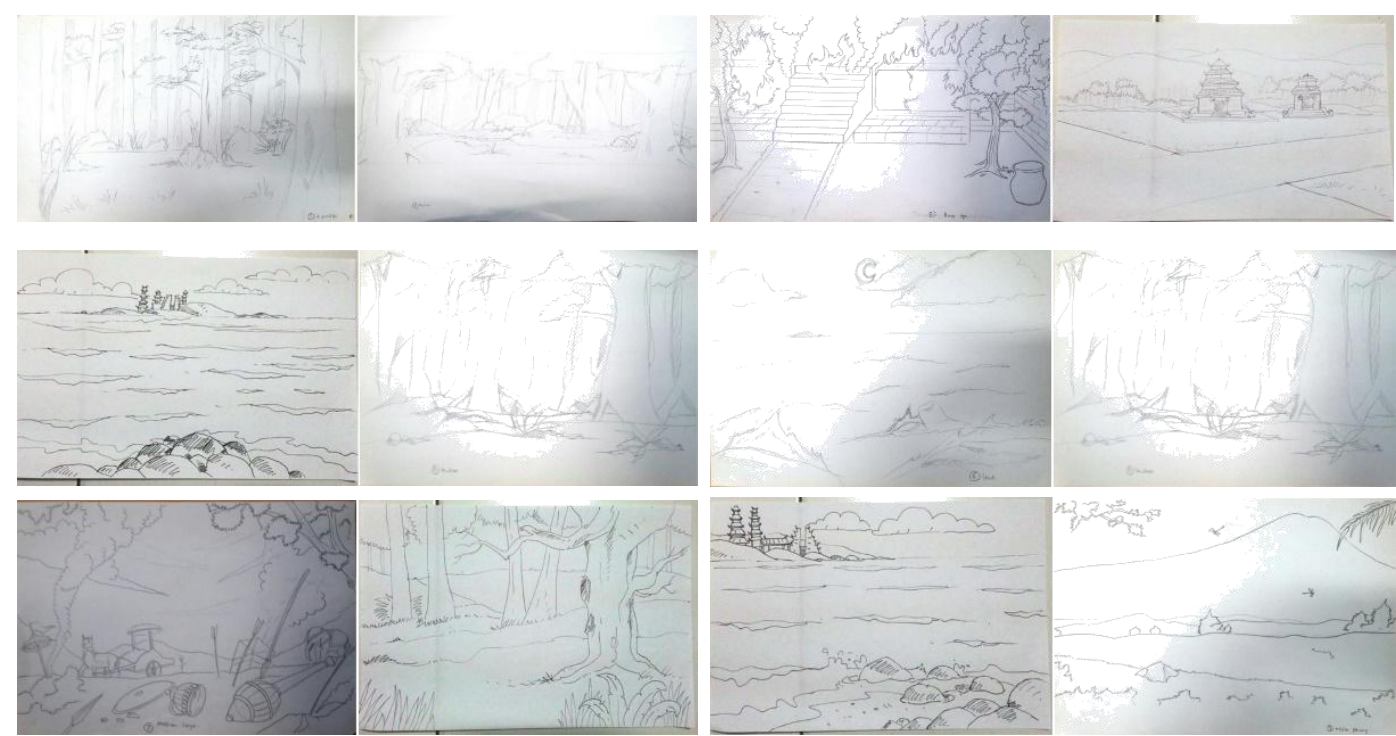

Gambar 5. Sketsa background pentas wayang orang Ramayana

Sumber: Dokumentasi penulis

\section{Pengumpulan Bahan}

Pada tahap ini dilkukan pembuatan dan pengumpulan bahan-bahan media yang digunakan dalam pembuatan perancangan ini, antara lain:Gambar obyek,pemodelan 3D obyek,audio, dananimasi.

\section{Pembuatan}

Pembuatan animasi menggunakan aplikasi pengolah audio, aplikasi pembuatan animasi 3D dan aplikasi pengolah video.

\begin{tabular}{|c|c|c|c|}
\hline No & $\begin{array}{c}\text { Uraian } \\
\text { Adegan }\end{array}$ & Volume & Rincian Adegan \\
\hline 1 & $\begin{array}{l}\text { SINTA } \\
\text { DICULIK }\end{array}$ & $\begin{array}{c}4 \\
\text { Animasi }\end{array}$ & $\begin{array}{l}\text { Pengembaraan Rama, Shinta dan Laksmana (durasi } 35 \text { menit) } \\
\text { - Animasi Hutan : (durasi } 19 \text { menit) } \\
\text { - Rama, Shinta, dan Laksmana berburu di hutan } \\
\text { - Rahwana dan Kalamarica yang berubah menjadi cakil ikut } \\
\text { masuk hutan }\end{array}$ \\
\hline
\end{tabular}




\begin{tabular}{|c|c|c|c|}
\hline No & $\begin{array}{c}\text { Uraian } \\
\text { Adegan }\end{array}$ & Volume & Rincian Adegan \\
\hline & & & $\begin{array}{l}\text { - Kalamarica berubah menjadi Kijang emas menggoda Sinta, } \\
\text { Rama dan Laksmana mengejar kijang emas } \\
\text { - Rahwana menggoda Shinta } \\
\text { - Penculikan Shinta oleh Rahwana. } \\
\text { - Animasi Hutan : (durasi } 7 \text { Menit) } \\
\text { - Laksmana mengejar kijang emas } \\
\text { - Kijang emas (Kalamarica) berubah menjadi cakil, bertarung } \\
\text { - Rengan laksmana. } \\
\text { - Ramimasi Mega/Awan : (durasi } 5 \text { menit) } \\
\text { - Garuda jatayu kiprah } \\
\text { - Perang dengan rahwana, jatayu kalah } \\
\text { Animasi Daratan : (durasi } 4 \text { menit) } \\
\text { - Jatayu jatuh ke daratan } \\
\text { - Jatayu memberitahu bahwa shinta diculik oleh Rahwana }\end{array}$ \\
\hline 2 & $\begin{array}{l}\text { PERANG } \\
\text { SAUDARA } \\
\text { SUGRIWA } \\
\text { SUBALI }\end{array}$ & $\begin{array}{c}1 \\
\text { Animasi }\end{array}$ & $\begin{array}{l}\text { Perang Sugriwa dan Subali (durasi } 12 \text { menit) } \\
\text { - Animasi Medan Perang dengan backgroud pepohonan : }\end{array}$ \\
\hline
\end{tabular}




\begin{tabular}{|c|c|c|c|}
\hline No & $\begin{array}{l}\text { Uraian } \\
\text { Adegan }\end{array}$ & Volume & Rincian Adegan \\
\hline & & & $\begin{array}{l}\text { - Sugriwa bertarung dengan Subali memperebutkan Dewi } \\
\text { - Rama dan Anoman datang. Karena mereka tidak mau dilerai, } \\
\text { anoman meminta rama memanah salah satu dari mereka. } \\
\text { - Subali yang terkena panah Rama.Subali gugur. } \\
\text { - Sugriwa dan bala tentara kerabergabung dengan Rama } \\
\text { mencari Shinta }\end{array}$ \\
\hline 3 & $\begin{array}{l}\text { ANOMAN } \\
\text { DUTA }\end{array}$ & $\begin{array}{c}4 \\
\text { Animasi }\end{array}$ & $\begin{array}{l}\text { Anoman Duta (durasi } 26 \text { menit) } \\
\text { - AnimasiKerajaan di hutan, bebatuan bertahta sebagai } \\
\text { singgasana : (durasi } 12 \text { menit) } \\
\text { - Rama dan Sugriwa berembuk untuk memilih duta ke Alengka } \\
\text { - Anoman ditunjuk sebagai utusan untuk ke Alengka } \\
\text { - Animasi Daratan : (durasi } 7 \text { menit) } \\
\text { - Anoman diberikan cincin Rama sebagai tanda saat bertemu } \\
\text { Shinta bahwa anoman utusan Rama }\end{array}$ \\
\hline
\end{tabular}




\begin{tabular}{|c|c|c|c|}
\hline No & $\begin{array}{c}\text { Uraian } \\
\text { Adegan }\end{array}$ & Volume & - Animasi Awan dan Anoman Duta : (durasi 1 menit) \\
\hline & & & $\begin{array}{l}\text { - Perjalanan Anoman menuju Alengka } \\
\text { Animasi Pantai : (durasi } 6 \text { menit) } \\
\text { - Anoman berkelahi dengan raksasa buaya } \\
\text { - Raksasa buaya kalah, bersedia menyebrangkan ke Alengka. }\end{array}$ \\
\hline 4 & $\begin{array}{l}\text { TAMAN } \\
\text { ALENGKA }\end{array}$ & $\begin{array}{c}4 \\
\text { Animasi }\end{array}$ & $\begin{array}{l}\text { Anoman Obong (durasi } 22 \text { menit) } \\
\text { Animasi Taman : (durasi } 16 \text { menit) } \\
\text { - Rahwana membujuk Shinta, dibantu oleh Trijatha. } \\
\text { - Rahwana datang dan menunjukkan cincin rama sebagai bukti } \\
\text { utusan Rama } \\
\text { Animasi Alun-alun : (durasi } 4 \text { menit) }\end{array}$ \\
\hline
\end{tabular}




\begin{tabular}{|c|c|c|c|}
\hline No & $\begin{array}{c}\text { Uraian } \\
\text { Adegan }\end{array}$ & Volume & Rincian Adegan \\
\hline & & & $\begin{array}{l}\text { - Anoman bertarung dengan para raksasa. } \\
\text { - Anoman tertangkap } \\
\text { - Animasi Kerajaan Terbakar Api : (durasi } 1 \text { menit) } \\
\text { - Anoman dibakar } \\
\text { - Anoman lepas, kemudian membakar kerajaan alengka } \\
\text { Animasi Bara Api membesar : (durasi } 1 \text { menit) } \\
\text { - Bara api membesar membakar kerajaan Alengka }\end{array}$ \\
\hline 5 & $\begin{array}{l}\text { RAMA } \\
\text { TAMBAK }\end{array}$ & $\begin{array}{c}3 \\
\text { Animasi }\end{array}$ & $\begin{array}{l}\text { Rama Tambak (durasi } 10 \text { menit): } \\
\text { - Animasi Daratan : (durasi } 2 \text { menit) } \\
\text { - Anoman bertemu dengan Rama, Laksmana, Sugriwa dan Bala } \\
\text { tentara Kera } \\
\text { - Mereka merundingkan cara untuk menuju Alengka yang ada } \\
\text { di seberang lautan }\end{array}$ \\
\hline
\end{tabular}




\begin{tabular}{|c|c|c|c|}
\hline No & $\begin{array}{l}\text { Uraian } \\
\text { Adegan }\end{array}$ & Volume & Rincian Adegan \\
\hline & & & $\begin{array}{l}\text { - Animasi Tambak Lautan : (durasi } 6 \text { menit) } \\
\text { - Bala Tentara kera membuat jalan melintasi lautan } \\
\text { Animasi Jalan Tambak Lautan Jadi : (durasi } 2 \text { menit) } \\
\text { - Jalan ke Alengka melintasi lautan jadi. } \\
\text { - Bala Tentara kera menuju Alengka }\end{array}$ \\
\hline 6 & $\begin{array}{l}\text { BARATAYU } \\
\text { DA KUDUP } \\
\text { SARI } \\
\text { PAWAGA }\end{array}$ & $\begin{array}{c}2 \\
\text { Animasi }\end{array}$ & $\begin{array}{l}\text { Perang besar (durasi } 15 \text { menit) } \\
\text { - Animasi Medan Laga : (durasi } 7 \text { menit) } \\
\text { - Perang besar kubu Rama dengan Alengka } \\
\text { - Animasi Berserakan puing puing kereta, gajah dan property } \\
\text { tameng, gada, tombak dsb : (durasi } 8 \text { menit) } \\
\text { Perang besar kubu Rama dengan Alengka sampai Rahwana } \\
\text { gugur. }\end{array}$ \\
\hline
\end{tabular}




\begin{tabular}{|c|c|c|c|}
\hline No & $\begin{array}{c}\text { Uraian } \\
\text { Adegan }\end{array}$ & Volume & Rincian Adegan \\
\hline 7 & $\begin{array}{l}\text { SINTA } \\
\text { OBONG }\end{array}$ & $\begin{array}{c}3 \\
\text { Animasi }\end{array}$ & $\begin{array}{l}\text { Sintha Obong (durasi } 5 \text { menit) } \\
\text { - Rama dan Shinta dipertemukan kembali } \\
\text { Animasi Bara api: (durasi } 2 \text { menit) } \\
\text { - Pembuktian kesucian sinta } \\
\text { Animasi Bara api membesar : (durasi } 1 \text { menit) } \\
\text { - Shinta berada dalam bara api } \\
\text { - Rama dan Shinta bersatu kembali }\end{array}$ \\
\hline
\end{tabular}

\section{Pengujian}

Pengujian dilakukan dengan menggunakan user acepptence test, dimana hasil animasi didiskusikan bersama dengan dalang dan beberapa pihak yang terkait dengan pementasan sendratari cerita Ramayana Full Story "Barat ayuda Kudup SariPawaga". 


\section{Distribusi}

\section{Pengemasan Karya}

Karya yang sudah final, kemudian didistribusikan dengan menggunakan media DVD. Adapun 2 jenis hasil karya yang tersimpan dalam 2 jenis DVD, yaitu: master animasi dan video interaktif background animasi.

\section{Strategi penerapan background perancangan multimedia interaktif untuk pentas wayang orang ramayana}

Pementasan sendratari cerita Ramayana Full Story "Barat ayuda Kudup SariPawaga" diselenggarakan di open stage Taman Balekambang Kota Surakarta. Visualisasi animasi background ditampilkan menggunakan LCD Projector7200 Lumens dengan layar display ukuran $4 \mathrm{X} 3$ meter. Karena digunakan sebagai background pentas, maka LCD Projector akan disorotkan daribelakang layar sehingga tidak mengganggu pemain sendratari yang sedang pentas.

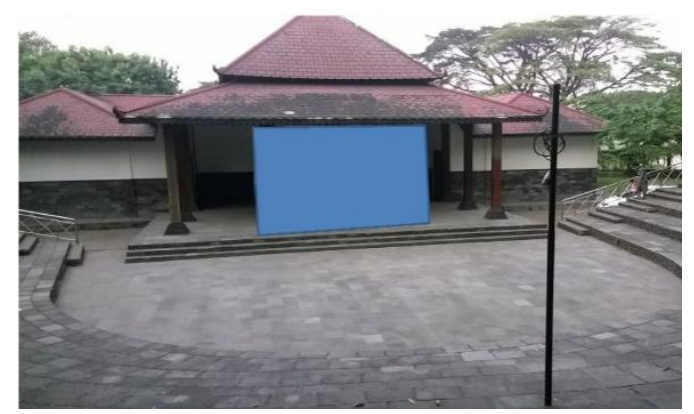

Gambar 6. Posisi layar di open stage Sumber: Dokumentasi penulis

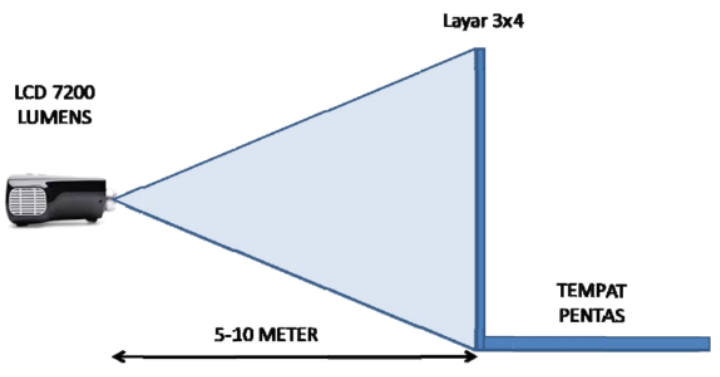

Gambar 7. Konsep penerapan background Sumber: Dokumentasi penulis 

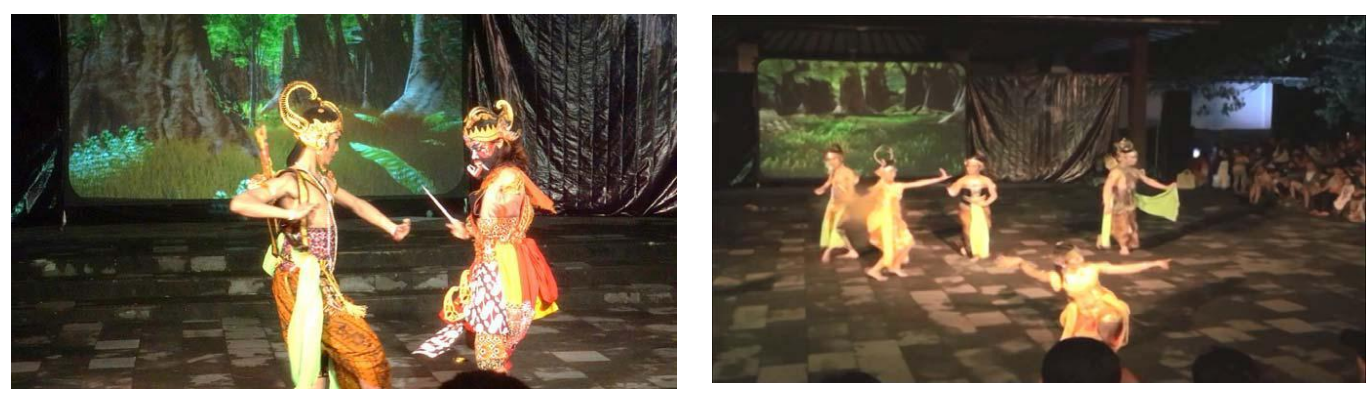

gambar 8. Hasil penerapan pada pentas wayang orang Ramayana

Sumber: Dokumentasi pribadi

\section{PENUTUP}

\section{Kesimpulan}

Dari proses produksi hingga pementasan, dapat disimpulkan sebagai berikut: Pementasan lebih menarik karena pada pementasan sendratari sebelumnya tidak menggunakan background, layar background yang digunakan (4X3 meter) masih terlalu kecil jika dibandingkan dengan lebar tempat pementasan yang mencapai 9 meter sehingga kurang ada kesan menyatu antara pemain dan background yang ada, penggunaan LCD Projector yang menghasilkan cahaya terang, tidak mendukung dalam menggambarkan emosi pada setiap adegan, tampilan background juga terganggu dengan sorot lighting yang terkadang lebih terang, dan properti pada animasi background terkait tema cerita masih kurang, misal : properti kerajaan dan properti perang.

\section{Saran}

Berikut beberapa saran yang dapat diperhatikan kedepan untuk menghasilkan tampilan animasi background yang lebih baik. Antara lain: Teknologi LED display memiliki tingkat penanganan yang lebih mudah, hasil tampilan lebih bagus, dan mampu diseting untuk mendukung visualisasi emosi pada setiap adegan, lebar display untuk background sebaiknya tidak terlalu jauh perbandingannya dengan lebar tempat pementasan, penggunaan lighting pada pentas harus memperhatikan setiap adegan. Pada saat adegan membutuhkan 
lighting redup, pengambilan rekaman gambar adegan tidak kekurangan cahaya, demikian juga saat adegan membutuhkan cahaya yang terang, tidak mengganggu tampilan background, penggunaan lighting lebih dari satu titik lokasi sorot akan memberikan pencahayaan yang lebih merata pada pentas, penggunaan properti yang sesuai dengan tema cerita, akan memperkuat imajinasi penonton saat menikmati setiap adegan.

\section{DAFTAR PUSTAKA}

\section{Buku dan jurnal}

Green, T. D., Brown, A., 2002. Multimedia Project In The Classroom. USA: Corwin Press, Inc.

Hersapandi., 1999. Wayang Wong Sriwedari, Dari Seni Istana Menjadi Seni Komersil. Yogyakarta: Yayasan Untuk Indonesia.

Luther, Arc C., 1994. Authoring InteractiveMultimedia. Boston: AP Professional.

Soedarsono., 2002. Seni Pertunjukan Indonesia di Era Globalisasi. Yogyakarta: Gadjah Mada University Press.

Turban., dkk., 2002. Aplikasi Multimedia Interaktif. Yogyakarta: Paradigma.

\section{Internet}

KBBI Daring. Wayang[website]. Jakarta: Badan Pengembangan dan Pembinaan Bahasa, Kementerian Pendidikan dan Kebudayaan Republik Indonesia. Tersedia di http://badanbahasa.kemdikbud.go.id/kbbi/ [tanggal dan waktu diakses 12 desember 2016 pukul 23.12 pm].

Digital view studio. Mengenal multimedia[website]. Jakarta: Tersedia di $<$ http://digitalview.weebly.com/mengenal-multimedia.html> [tanggal dan waktu diakses 12 desember 2016 pukul 22.17 pm].

Negeriku Indonesia. Kesenian wayang wong[website]. Jakarta: Tersedia di <http://www.negerikuindonesia.com/2015/03/kesenian-nusantara-wayangwong.html> [tanggal dan waktu diakses 21 desember 2016 pukul 11.17 am]. 